\title{
Current Knowledge and Recent Advances in Marine Dinoflagellate Transcriptomic Research
}

\author{
Muhamad Afiq Akbar ${ }^{1}$, Asmat Ahmad ${ }^{1}$, Gires Usup ${ }^{2}$ and Hamidun Bunawan ${ }^{3, *}$ \\ 1 School of Bioscience and Biotechnology, Faculty of Science and Technology, Universiti Kebangsaan Malaysia, \\ Bangi 43600, Malaysia; muhdafiq.akbar@gmail.com (M.A.A.); asmat@ukm.edu.my (A.A.) \\ 2 School of Environmental and Natural Resources Sciences, Faculty of Science and Technology, \\ Universiti Kebangsaan Malaysia, Bangi 43600, Malaysia; gires@ukm.edu.my \\ 3 Institute of Systems Biology, Universiti Kebangsaan Malaysia, Bangi 43600, Malaysia \\ * Correspondence: hamidun.bunawan@ukm.edu.my; Tel.: +60-389-214-546
}

Received: 27 October 2017; Accepted: 15 January 2018; Published: 1 February 2018

\begin{abstract}
Dinoflagellates are essential components in marine ecosystems, and they possess two dissimilar flagella to facilitate movement. Dinoflagellates are major components of marine food webs and of extreme importance in balancing the ecosystem energy flux in oceans. They have been reported to be the primary cause of harmful algae bloom (HABs) events around the world, causing seafood poisoning and therefore having a direct impact on human health. Interestingly, dinoflagellates in the genus Symbiodinium are major components of coral reef foundations. Knowledge regarding their genes and genome organization is currently limited due to their large genome size and other genetic and cytological characteristics that hinder whole genome sequencing of dinoflagellates. Transcriptomic approaches and genetic analyses have been employed to unravel the physiological and metabolic characteristics of dinoflagellates and their complexity. In this review, we summarize the current knowledge and findings from transcriptomic studies to understand the cell growth, effects on environmental stress, toxin biosynthesis, dynamic of HABs, phylogeny and endosymbiosis of dinoflagellates. With the advancement of high throughput sequencing technologies and lower cost of sequencing, transcriptomic approaches will likely deepen our understanding in other aspects of dinoflagellates' molecular biology such as gene functional analysis, systems biology and development of model organisms.
\end{abstract}

Keywords: dinoflagellates; transcriptomics; harmful algae blooms; next-generation sequencing; RNA-seq

\section{Introduction}

Dinoflagellates are a large group of phytoplanktonic organisms that reside in marine ecosystems and play a crucial role in food webs and in balancing ecosystem energy fluxes [1]. Dinoflagellates are found in a range of marine ecosystems including estuaries, mangroves and deep-sea environments, and some exist as symbionts with other organism such as coral and epiphytes of seaweeds and seagrass [2-6]. Their lifestyle ranges from mixotrophic through to heterotrophic and autotrophic [7-9]. They also have been reported to be the major cause of the harmful algae blooms (HABs), sometimes referred to as 'red tide' events in the ocean, and may result in death of marine mammals and affect human health due to the accumulative effect of toxins moving throughout the food chain when contaminated seafood is consumed [10,11].

Dinoflagellates possess two dissimilar flagella, transverse flagellum encircling the cell allowing the dinoflagellate to maneuverer and longitudinal flagellum assisting forward movement by propelling back and forth [12]. Dinoflagellates have atypical genomes, being of an exceptional size (1-270 Gb), with chromosomes that are in liquid-crystalline form and permanently condensed throughout the cell 
cycle, contain few histones and have unusual base replacement where $70 \%$ of thymine is replaced with 5-hydroxymethyluracil [12]. To date, only three dinoflagellates draft genomes have been sequenced from the genus Symbiodinium. A complete genome sequence is not yet available for most dinoflagellates; therefore, attempts to study dinoflagellates at the genomic level are difficult [13-16]. Studies of the transcriptome can be a practical alternative in such cases [17], commonly being used in large-scale studies of gene expression using either microarrays or next-generation sequencing (NGS) RNA-seq [18]. Transcriptomics approaches are becoming more popular in the study of dinoflagellates, with more than 175,000 expressed sequence tags (EST) sequences available to date. The various aspects of biology, genome structure and gene regulation of dinoflagellates have been discussed in a review paper by Lin [12]. Thus, in this review, we intend to summarize the current dinoflagellate knowledge using the transcriptomics approach, as well as the future direction in this promising technology.

\section{Current Findings from Marine Dinoflagellates Transcriptomics Research}

\subsection{Dinoflagellates' Growth and Gene Regulation}

Transcriptomics approaches to dinoflagellates' study are the foundation for the elucidation of the unique metabolism and growth regulation of dinoflagellates at the molecular level. Transcriptomics profiling of the ciguatera-causing dinoflagellate Gambierdiscus caribaeus under different culture conditions shows the adaptations of G. caribaeus in marine ecosystems. This dinoflagellate is mixotrophic, having the ability to use different sources of energy and carbon, instead of using a single trophic mode [19]. Further analysis of this pathway revealed that most dinoflagellates possess genes that permit the metabolic capability to utilize substrates such as acetate for carbohydrate biosynthesis and nitrogen via the ornithine-urea cycle and production of nitric oxide synthase [19]. Furthermore, EST analysis of Alexandrium fundyense strain CCMP 1719, originally isolated from the Gulf of Maine, revealed libraries encoding cyanate lyase also known as cyanase (cynS), which functions in the degradation of cyanate, a toxic nitrogen-containing compound, to produce carbon dioxide and ammonium [20]. The presence of an almost complete coding region of dinoflagellate-specific trans-spliced leader (DinoSL) in the cynS gene suggests that this gene was dinoflagellate originated and was likely functional [20-23]. However, it is still unclear whether A. fundyense takes up cyanate from the environment or uses cyanate intracellularly from spontaneous degradation of urea, as there is no cyanate transporter gene presence in the transcriptome data [20]. Previously, Prorocentrum donghaiense demonstrated the ability to utilize cyanate as its sole nitrogen source [24]. To the best of our knowledge, this is the first report of $c y n S$ gene presence in dinoflagellates.

The atypical genomic arrangements in dinoflagellates include dinokaryotic nuclei, lack of nucleosomes, permanently-condensed chromosomes and an attachment to the nuclear envelope, the result of which is that the chromosomes appear to be in a liquid crystal formation in the nucleus [13]. Generally, in the place of histones and nucleosomes, a small amount of "histone-like" proteins is present [25]; further study on the dinoflagellates transcriptomics analysis discovered several genes encoding for histones and other nucleosome-associated proteins. This finding provides new perspective on the genome arrangement in dinoflagellates, which was previously reported to be different from other atypical eukaryotes [26]. Another study also identified a full suite of histone and histone-modifying genes transcribed at a low level in the dinoflagellate Lingulodinium polyedrum [27]. Twenty histone-encoding genes and 53 histone-modifying enzymes were also found in the Symbiodinium transcriptome [28], and a full suite of histone genes was also found in both Gambierdiscus australes and Gambierdiscus belizeanus [29]. Lin et al. [26] suggest that previous efforts to detect genes encoding histones and other nucleosome-associated proteins at mRNA level most likely failed due to differential or low-level expression. Correspondingly, it is possible that these histones and other nucleosomal proteins may be involved in the regulation of gene expression, instead of the organization of chromatins in dinoflagellates as with typical histone proteins. 
The unusual genome structure of dinoflagellates raises the question of whether gene regulation in dinoflagellates is controlled by transcription factors. Analysis of the transcriptome profile of Symbiodinium spp. found that the transcription factors in this organism are completely different from typical eukaryotes [28]. Common domains of sequence-specific transcription factors such as zinc fingers, helix loop helix, AP2 or homeobox domains are not present in the transcriptomics data. However, analysis of the Symbiodinium spp. genome sequence revealed the presence of those transcription factors suggesting that some genes in dinoflagellates are under the control of sequence-specific transcription factors [14,15]. Transcription factors in dinoflagellates are less abundant in comparison to those present in other protists such as Plasmodium, and it has been suggested that this low abundance may be a genomic signature for dinoflagellates [28]. Numerous novel dinoflagellate genes that are involved in gene regulation at the transcriptional and post-transcriptional level have been discovered in the Alexandrium catenella transcriptome, including homologs for a forkhead box protein (FOXL1), multiprotein bridging factor type 1 (MBF1), RAP2.4 and two identified TATA box-binding protein interacting proteins (TBP-IP; RuvB-like 1 and 2) [30]. Interestingly, the genome sequence of Symbiodinium kawagutii possesses a TATA-box binding protein (TBP)-like factor instead of TBP, which has high affinity toward the TTTT promoter motif [15]. The authors also suggested that the typical eukaryotic TATA box promoter motif is replaced by TTT(T/G) in dinoflagellates.

Only recently, a number of studies have started looking into the diversity of miRNA in dinoflagellates using a transcriptomics approach [31-34]. Baumgarten et al. [31] discovered that Symbiodinium microadriaticum not only produce miRNA, but also small (or short) interfering RNA (siRNA). The authors indicated that these small RNA (smRNAs) may potentially regulate a large fraction of protein coding genes and processes in Symbiodinium using the RNAi pathway. Based on computational analysis of Alexandrium tamarense expressed sequence tags (EST), some miRNAs were targeted to housekeeping genes such as crystalline ribonucleoprotein complex and ribosomal protein [32]. Moreover, there were other targeted genes by these miRNAs with more diverse functions such as pyridine nucleotide-disulfide oxidoreductase and naringenin-chalcone synthase.

Genome data of S. kawagutii revealed that 2557 genes with known function are potentially controlled by miRNA. Most of the genes serve a wide range of biological processes including carbohydrate metabolism, transcription regulation and biosynthesis of amino acids and antibiotics [15]. Interestingly, miRNAs identified as small RNA-degrading nucleases 1 and 3 have been reported to have themselves an miRNA target [15]. However, not all protein coding genes are regulated by miRNAs. Dagenais-Bellefeuille et al. [35] recently found that circadian regulation gene expression of luciferase binding protein in Lingulodinium polyedrum is not mediated by miRNAs, although transcriptomics data show the presence of miRNAs in L. polyedrum.

\subsection{Environmental Stress}

The dinoflagellates possess various abilities to alter their transcriptome profiles to adapt to the environment. Adaptation to stress is important to ensure dinoflagellates' survival in marine ecosystems (Table 1). A number of studies have been done to understand the effect of temperature on dinoflagellates from the genus Symbiodinium, which is an important dinoflagellate group that forms symbioses to create the foundation of coral reefs. Climate change is causing much irreversible damage to reefs such as coral bleaching. The role of Symbiodinium in coral bleaching is yet to be uncovered, but it is generally thought that Symbiodinium are more vulnerable to thermal stress than their coral host [36]. Transcriptomic data from Symbiodinium showed that some dinoflagellates from this genus exhibit plasticity and can upregulate a large number of genes during elevated temperatures in marine ecosystems. The authors also suggested that during heat stress, Symbiodinium cells were participating in sexual rather than asexual reproduction [36]. Transcriptomics data showed most enriched Gene Ontology (GO) was specific to meiosis-related genes. A number of meiosis-related genes present in another Symbiodinium transcript during heat stress provide further support for the heat-induced sexual reproduction life cycle in Symbiodinium [37]. Furthermore, the transcriptional 
response of Symbiodinium to heat stress included genes typically upregulated during stress responses such as the antioxidant network and the molecular chaperones, cellular components such as the core photosynthesis machinery, integral light harvesting protein complexes and enzymes such as fatty acid desaturases [37].

Table 1. Summary of transcriptomics studies in dinoflagellates relating to environmental stress.

\begin{tabular}{|c|c|c|c|}
\hline Stress Parameter & Investigated Species & Platform & Reference \\
\hline \multirow[t]{6}{*}{ Nitrogen limitation } & Karenia brevis & Microarray & [38] \\
\hline & A. tamarense & Massively parallel signature sequencing (MPSS) & [39] \\
\hline & Scrippsiella trochoidea & Illumina HiSeq & [40] \\
\hline & A. fundyense & MPSS & [41] \\
\hline & & Roche 454 & [20] \\
\hline & Alexandrium minutum & Microarray & [42] \\
\hline \multirow[t]{7}{*}{ Phosphorus limitation } & K. brevis & Microarray & [38] \\
\hline & P. donghaiense & Illumina HiSeq & [34] \\
\hline & A. tamarense & MPSS & [39] \\
\hline & A. fundyense & MPSS & [37] \\
\hline & S. trochoidea & Illumina HiSeq & [36] \\
\hline & A. minutum & Microarray & [42] \\
\hline & Karenia mikimotoi & Suppression subtractive hybridization (SSH) & {$[43,44]$} \\
\hline \multirow[t]{4}{*}{ Thermal stress } & Symbiodinium spp. & ABI Prism & [45] \\
\hline & & Illumina HiSeq & [46] \\
\hline & & Illumina HiSeq & [47] \\
\hline & & Illumina HiSeq & [37] \\
\hline \multirow{2}{*}{ Parasite exposure } & A. fundyense & Illumina HiSeq & [1] \\
\hline & A. minutum & Microarray & [48] \\
\hline Light intensity & Symbiodinium sp. & - & [9] \\
\hline Carbon dioxide accumulation & K. brevis & llumina HiSeq & [49] \\
\hline Salinity & Oxyrrhis marina & Roche 454 & [50] \\
\hline
\end{tabular}

Analysis of the $S$. trochoidea transcriptome under nitrogen limitation revealed significant effects on electron transport chain components, photosynthetic pathways, nitrogen, lipid, carbohydrate, amino acid and stress-related metabolism [40]. Among the upregulated transcripts in S. trochoidea, glutamine synthetase and glutamate synthase were present, indicating increased investment in cellular ammonium assimilation potential [40]. The toxic alga Prymnesium parvum also had an overall higher expression of glutamine synthetase and glutamate synthase under nitrogen limited conditions, while the $K$. brevis transcriptome showed upregulation in glutamine synthase, nitrate/nitrite transporters and ammonium transporter genes [38,51]. Thus, these findings indicate that dinoflagellates may remodel their intracellular metabolism to utilize organic nitrogen such as urea under nitrogen limited conditions. Downregulation of the photosynthetic pathway also may couple with nitrogen limitation in dinoflagellates. For example, genes representing the transfer of electrons in Photosystems I and II along with several addition members of the photosynthetic pathway such as Photosystem Q, the cytochrome complex and flavodoxin were significantly downregulated in S. trochoidea under nitrogen limitation [40]. Yang et al. [42] showed that both photosynthetic performance and the related gene expression are most affected under nitrogen limitation in A. minutum. Interestingly, following the addition of nitrogen back to the nitrogen-limited $K$. brevis, among the earliest responding genes were pentatricopeptide repeat (PPR) proteins responsible for proteins involved in chloroplast and mitochondria RNA processing, which may help in reactivation of energy production, especially toward the photosynthesis pathway [38]. However, the authors demonstrated that reactivation of energy production in K. brevis is achieved at the post-transcriptional level due to the presence of the spliced leader (SL) on PPR protein mRNA.

During phosphorus limitation, genes related to dissolved organic phosphorus (DOP) hydrolysis, carbon fixation, nitrate assimilation, glycolysis and cellular motility were upregulated in P. donghaiense [34]. The study suggested that under phosphorus limitation, $P$. donghaiense can utilize various types of phosphoester substrates such as nucleic acids, ATP and lipids as alternative sources of phosphate, most probably due to the alkaline phosphatase and a nuclear interacting factor (NLI)-like phosphatase gene that are upregulated during phosphorus limitation. G1/S-specific cyclin gene, important for the 
progression of the cell cycle, was markedly downregulated during phosphorus limitation in P. donghaiense, which is consistent with several reports that phosphorus limitation will arrest dinoflagellates' cell cycle at the $\mathrm{G} 1$ phase at the cellular level [52,53]. Interestingly, the transcriptome response toward phosphorus limitation in K. brevis showed no significant response in phosphorus uptake or utilization, although there is strong evidence that suggests dinoflagellates change their phosphorus uptake or utilization behavior at the cellular level $[38,52,54]$. Based on these results, we can postulate that the response toward phosphorus limitation may occur at the post-transcriptional level, with some transcripts undergoing alternative splicing and regulation via miRNAs. For example, miRNA sequencing revealed 17 miRNAs, potentially regulating 3268 protein-coding genes in P. donghaiense during phosphorus limitation [34].

Recently, high throughput sequencing of the Cochlodinium polykrikoides transcriptome revealed that exposure to the algaecide copper sulfate caused genes related to the photosystem to be downregulated, while most of the mitochondria related genes were upregulated [11]. Prorocentrum minimum also showed low expression of photosynthesis-related genes when exposed to biocide copper sulfate. This finding is supported by a study on the effect of algicide copper on various physiological parameters in C. polykrikoides that showed the photosynthetic process of the exposed cells was damaged [55]. Thus, copper stress on dinoflagellates reduces the efficiency of photosynthesis and leads to a lower growth rate and may induce cells' death. However, Guo et al. [11] suggested that upregulation of mitochondria-related genes may serve as a strategy for dinoflagellates to increase the probability of cell survival by boosting the oxidative phosphorylation process.

Physical interaction or exposure to chemical signals from predators demonstrated a strong response of the dinoflagellates' transcriptome [1]. RNA sequencing revealed that a total of 14,882 genes in treated and corresponding control samples were found to be differentially expressed at a significant level in A. fundyense at $6 \mathrm{~h}$ and $96 \mathrm{~h}$ after exposure to the parasite Amoebophyra, with most of the genes being differentially expressed at the 96-h time point. The study indicated that the level of threat from Amoebophyra at the 6-h time points is too low to trigger the transcriptome response. The early response of $A$. fundyense needs to be further examined following several studies that showed the presence of post-transcriptional regulation in dinoflagellates [56,57].

A study on the grazing effect from copepods on A. minutum revealed that a very low number of genes was differentially expressed after three days of exposure to copepods [48]. Although this study found that grazers induced toxin production in dinoflagellates and this is supported by several studies on grazing effect to the toxin production in dinoflagellates, two upregulated genes that could be annotated in this study are unlikely to be directly involved in PSP toxin synthesis [48,58-60].

\subsection{Toxin Biosynthesis}

Progress towards understanding the molecular mechanism behind the toxin production of harmful dinoflagellates remains poorly understood due to the lack of dinoflagellate genomic data. Although the paralytic shellfish poisoning (PSP) toxin biosynthesis mechanism has been proposed to be similar to cyanobacteria, the effort to identify genes involved in PSP production fully is more complicated than in cyanobacteria owing to the exceptionally large genome size and high gene copy number in dinoflagellates [61]. Before the transcriptomics approach was widely used, several strategies were employed by researchers to understand the molecular mechanism behind toxin production in dinoflagellates such as differential display analysis of mRNA and degenerate PCR [62-66]. Among dinoflagellates' toxins, the PSP toxin biosynthesis pathway is the most well-studied toxin using the transcriptomics approach.

Comparative transcriptome analysis of toxic versus non-toxic dinoflagellates is one of the strategies used by researchers to elucidate the molecular mechanism of PSP toxin biosynthesis $[67,68]$. Comparison of toxic versus non-toxic strains of the A. minutum transcriptome revealed many genes highly expressed in toxic strains. However, some of these potential PSP toxin production genes could not be annotated due to a lack of known similar sequences [68]. Furthermore, in silico analysis of A. minutum compared with the cyanobacterial PSP toxin gene cluster yielded no evidence for this 
gene cluster, suggesting that PSP toxin production in A. minutum is different from cyanobacteria [68]. The dinoflagellate $s x t A$ transcript differs from its cyanobacterial counterpart by the presence of signal peptides, SL sequences and polyA-tails and also in its GC content [69]. Comparative transcriptome analysis of Alexandrium catenella with its non-toxic mutant showed that 35 genes were found to be differentially expressed between these two strains [67]. The authors of this study also speculated the A. catenella non-toxic mutant has more active carbon fixation and a higher ATP requirement due to higher expression of genes involved in cellular metabolism such as fructose biphosphate aldolase. The A. catenella non-toxic mutant showed lower expression of the long isoform of the dinoflagellate sxt $A$ gene, which is responsible for the initiation of toxin biosynthesis. However, the expression of the short isoform of the dinoflagellate $s x t A$ gene showed no significant different between the toxic and non-toxic mutant strain of $A$. catenella [67]. Some toxin-related genes also have been reported to be widely present in non-toxic dinoflagellates [70]. These toxin-related genes may serve in other metabolic processes in dinoflagellate cells. The long isoform of the $s x t A$ gene that is only present in toxic dinoflagellates may indicate that this gene is directly involved in PSP toxin production. Further investigation using the PCR approach into 28 saxitoxin-producing and non-producing dinoflagellate strains from six different genera for the presence of genomic sxt $A$ homologs revealed a very good correlation between the presence of the long isoform of $s x t A$ genes and saxitoxin production, except in three strains of non-toxic $A$. tamarense, for which the amplified long isoform of $s x t A$ gene was present [69].

Many dinoflagellates' toxins including brevetoxins (BTXs), ciguatoxins (CTXs), maitotoxins (MTXs) and yessotoxins (YTXs) are polyketides, and the construction of all polyketides is directed by a family of enzymes: polyketide synthases (PKSs) [63,71]. Transcriptomic characterization of Azadinium spinosum revealed the full sets of biosynthetic enzymes' functions needed to synthesize the azaspiracid carbon backbone, which are responsible for the production of the potent toxin known as azaspiracids (AZAs) (Table 2) [10]. The first transcriptomics study, using next-generation sequencing on a toxic Gambierdiscus polynesiensis, identified 22 PKS transcripts that have homology to Type I PKS genes, and one of these transcripts has high sequence identity to the $5^{\prime}$ end of the $s x t A$ gene of $A$. fundyense [71]. However, the regulation of PKSs genes in dinoflagellates and the direct role of these genes in toxin production remains poorly understood. Microarray analysis in K. brevis showed that expression of PKSs genes did not change over the diel cycle despite evidence that toxin production is specific to certain diel phases or cell cycle stages in dinoflagellates [56]. The role of PKSs in toxin production of dinoflagellates needs to be further investigated, as several PKS genes found in dinoflagellates may potentially function as fatty acid synthases (FAS) [72,73]. In A. catenella strain ACT03, expression levels of two genes, S-adenosyl-homocysteine hydrolase (SAHH) and S-adenosylmethionine synthetase (SAM-S), which are involved in methylation and cell cycle progression, were speculated to correlate with toxin expression in A. catenella [30]. This finding is further supported by qPCR data of an A. catenella strain CAWD44 showing that the expression of SAHH and SAM-S-methionine aminopeptidase (MAP) genes were upregulated during saxitoxin production and the G2-M phase of the cell cycle [74].

Table 2. Summary of transcriptomics studies in dinoflagellates regarding toxin biosynthesis. PSP, paralytic shellfish poisoning; CTX, ciguatoxin; MTX, maitotoxin; BTX, brevetoxin; AZA, azaspiracid.

\begin{tabular}{cccc}
\hline Toxin Groups & Investigated Species & Sequencing Platform & References \\
\hline PSP & A. tamarense & Illumina HiSeq & {$[75]$} \\
& A. fundyense and A. minutum & Roche 454 & {$[69]$} \\
& A. minutum & ABI Prism & {$[68]$} \\
CTXs & A. catenella & Illumina HiSeq & {$[67]$} \\
& G. australes and G. belizeanus & Illumina HiSeq & {$[29]$} \\
MTXs & G. polynesiensis & Roche 454 & {$[71]$} \\
BTXs & G. australes and G. belizeanus & Illumina HiSeq & {$[29]$} \\
AZAs & K. brevis & Illumina HiSeq & {$[76]$} \\
\hline
\end{tabular}




\subsection{HABs Dynamics}

High-throughput sequencing of the total RNA extracted directly from natural microbial assemblages using an NGS platform has provided an unprecedented overview of the gene expression in natural microbial communities [77]. This so-called metatranscriptomics approach enables us to characterize dominant patterns in metatranscriptomes' diversity, transcriptional activity, sample-relatedness, taxonomic distribution and functional gene representation to indicate their involvement in environmentally-relevant processes including carbon metabolism and nutrient acquisition $[77,78]$. Knowledge from in situ transcriptomes during HABs will provide us deep insight regarding bloom dynamics. DinoSL may serve as a selective tool to separate dinoflagellate transcripts from other microbial assemblage transcripts in water columns [21-23]. The first application of DinoSL in dinoflagellates metatranscriptomics was documented by Lin et al. [26]. Since then, a number of studies has been reported regarding metatranscriptomics approaches to elucidate the dynamic nature of species' interactions during HABs and gene expression patterns during bloom development $[20,79,80]$.

Metatranscriptomics analysis over a 24-h period during the PSP bloom by A. fundyense at Long Island Sound in the United States showed that during the natural bloom, genes related to nitrogen uptake and assimilation, carbon fixation and saxitoxin production were more highly expressed when compared to the laboratory clonal cultures [20]. This study speculated that high expression of these genes is related to the competitive advantages of dinoflagellates against other competing organisms in the water column during the bloom formation. Metatranscriptome comparison of bloom sites with non-bloom sites showed that $42 \%$ of the taxonomically-annotated sequence reads in bloom site were from dinoflagellates, whereas only $\sim 20 \%$ of reads from the non-bloom site were from dinoflagellates [80]. In addition, metatranscriptome data under bloom conditions indicates there is increased expression of genes involved in cellular metabolism due to the higher growth rate of dinoflagellates during HABs. The study found that the increase in expression of genes related to cholesterol biosynthesis, whereas cholesterol degradation genes were under-expressed in the bloom sample relative to the surrounding non-bloom samples may be associated to resting cysts' formation. As the accumulation of dinosterols may be indicative of bloom termination as demonstrated by a number of studies, these transcriptome behaviors might indicate that during bloom formation, dinoflagellates synthesize more cholesterol to serve as energy storage during their resting stage $[81,82]$. To date, the number of studies that employed the metatranscriptomics approach to understand bloom dynamics is still relatively few, suggesting that more study is needed, especially regarding differently-expressed genes during bloom development such as bloom initiation, establishment and termination.

\subsection{Insight into Dinoflagellates' Phylogeny and Evolution}

A small number of studies has been reported on the presence of gene transfer in dinoflagellates through endosymbiotic gene transfer (EGT), lateral gene transfer (LGT) and horizontal gene transfer (HGT); however, the biological importance of these genes is not well understood [83-85]. The dinoflagellates are the only eukaryotic lineage that has been shown to have undergone several plastid replacement events, where native plastids are replaced with those acquired from other algal groups [84]. Transcriptomic studies have played a key part in the relationships between photosynthetic and heterotrophic lineages of dinoflagellates, how organelles such as plastids have been gained and lost and have been vital for documenting gene transfer events between symbiont and host [86-88]. Further analysis of K. mikimotoi transcriptomic data revealed proof of events of independent plastid-to-host gene transfer in individual fucoxanthin plastid lineages acquired through tertiary endosymbiosis [87]. In the case of K. brevis, a comparative analysis from EST data identified 30 nuclear-encoded plastid-targeted proteins that originated via EGT or HGT from multiple different sources. Interestingly, serial endosymbiosis and HGT provide a novel mechanism for K. brevis to thrive in iron-limited environments and may compete with other microorganisms in the water column due 
to the acquisition of plastocyanin originating from green algae. Dinophysis acuminata transcriptome data contained five nuclear-encoded plastid genes derived from multiple algae lineages [89].

\subsection{Symbiosis}

Some dinoflagellates occur as symbionts with other organisms. Photoautotrophic dinoflagellates in the genus Symbiodinium are among the most widely known for their association with coral [90]. Transcriptomic approaches revealed that dinoflagellates from the genus Symbiodinium contained a high number of genes related to antioxidative response such as genes encoding for the thioredoxin (Trx) protein superfamily, as well as genes for superoxide dismutase (SOD) and catalase (CAT) $[6,28]$. Lin et al. [15] reported that the $S$. kawagutii genome contains diverse set of antioxidative response genes such as SOD and ascorbate peroxidases. While most of the studies on SOD and CAT enzymes in Symbiodinium suggested these enzymes play a major role in coping with an increase of sea temperature to prevent coral bleaching [91-93], a number of studies in other organisms revealed that these enzymes may act in response to other types of environmental stress such as salinity, exposure to hydrogen peroxide and drought conditions [94-96]. Apart from the antioxidative response, cell adhesion proteins also play a role in maintaining coral-Symbiodinium symbiosis interaction [9]. Genes encoding for cell surface molecules such as Sushi, Von Willebrand factor type A, EGF and pentraxin domain containing 1 (Svep1) were downregulated during the event of induced bleaching in their coral host. Lin et al. [15] suggest that these cell surface molecules might play a role in host recognition. Previously, modification of the Symbiodinium cell surface molecules with trypsin or N-glycosidase has been shown to reduce the success rate of initial contact of Symbiodinium with their respective coral host, and characterization of these cell surface molecules is seen as important in coral-Symbiodinium symbiosis [97,98]. The most recent investigation on the genome evolution of Symbiodinium spp. suggests that symbiosis of these species with their coral host during retroposition likely occurred between 3.5 and 9.1 million years ago [99]. During this event, Symbiodinium started to develop genes for a symbiotic lifestyle including genes related to cell adhesion and a number of transport processes. The roles of calcium signaling and calcium-regulated proteins in the foundation of coral-Symbiodinium were proposed by Rosic et al. [6], as these genes are conserved in Symbiodinium and are proven to play a vital role during microbe-plant symbiosis $[100,101]$. However, further study of the role of these genes in dinoflagellates' symbiosis is highly recommended as these genes are reportedly expressed in several non-symbiont dinoflagellates such as K. brevis and A. fundyense [1,102].

Metagenomic approaches already revealed that dinoflagellates' phycosphere is heavily colonized by bacteria [103]. Several studies have been done to investigate bacteria-dinoflagellates association especially in terms of toxin production, dinoflagellates' mortality and nutrient exchange [104-106]. To study the impact of the presence of bacteria in dinoflagellates, transcriptomic approaches were employed to compare the gene expression of axenic and xenic cultures of $A$. tamarense [39]. In the presence of bacteria, the SAM-S and SAHH genes were among the downregulated genes. These genes have been previously reported to be associated with toxin production in dinoflagellates $[30,74]$. Thus, it seems possible that bacteria may influence toxin production level through these genes. Another group of genes that was affected by the presence of bacteria in A. tamarense were genes related to the photosynthesis processes [39]. The authors hypothesized that reduced photosynthetic activity in A. tamarense in the presence of bacteria affected the trophic state of $A$. tamarense. However, increased expression of photoprotection and oxidative stress response genes in A. tamarense xenic culture likely serves as response to cope with a decrease in the efficiency of the photosynthesis process.

Another transcriptomic study revealed an interesting relationship between alphaproteobacterium Dinoroseobacter shibae and P. minimum, where the symbiotic relationship during co-culture of D. shibae axenic culture and P. minimum starts a mutualistic phase where both dinoflagellates and bacteria were helping each other and a pathogenic phase where aged dinoflagellates are killed by this bacterium [107]. A similar pattern of this unique symbiosis was reported in the marine coccolithophore Emiliania huxleyi with bacteria Phaeobacter gallaeciensis, and a "Jekyll and Hyde" lifestyle has been proposed for the 
unique symbiosis between bacteria from clade Roseobacter with marine algae [108]. Transcriptomics analysis of the bacterium D. shibae revealed that quorum sensing, CtrA phosphorelay and flagella biosynthesis genes were involved in this mutualistic turned parasitic relationship, as these genes were upregulated during the early pathogenic phase and downregulated in the late pathogenic phase [107]. To date, transcriptomic studies regarding bacteria-dinoflagellates symbiosis remain limited, most probably due to the difficulty in obtaining and growing axenic culture.

\section{Future Perspectives and Conclusions}

With the advancement of NGS technology and the lower cost of sequencing, it is likely we will see more transcriptomic studies on dinoflagellates. Improving experimental design will benefit this field. Currently, a number of transcriptomic studies that are trying to elucidate dinoflagellates' stress responses are only using a single-species approach under different levels of stress. However, comparative gene expression from more than one species offers significant improvement for elucidation of dinoflagellates' transcriptome responses, as genes responsible for environment adaptation are more likely under strong evolutionary constraints and share common responses or adaptation strategies for coping with stress environments [109]. Comparative transcriptome analysis of toxic metal responses in the plants Arabidopsis thaliana and Arabidopsis halleri produces reliable results as $87 \%$ of the genes upregulated under excess copper in A. halleri are also upregulated in A. thaliana, indicating stable and functionally-relevant changes conserved among some plant species [110]. Comparative in silico analysis of cross-species transcriptomes can be used as a strategy to reduce the number of candidate genes for further functional analysis [111]. Strikingly, cross-species transcriptome analysis in 21 organisms from four kingdoms (Plantae, Animalia, Fungi and Bacteria) revealed broadly conserved responses during oxygen deprivation associated with several metabolic processes such as glycolysis, fermentation, alternative respiration, metabolite transport, reactive oxygen species amelioration, chaperone activity and ribosome biogenesis [112]. Thus, we believe that future experiments should include cross-species comparison of dinoflagellate transcriptomes based on strong evidence of this approach's success and the fact that it has been used widely, particularly in plant stress response studies.

Nowadays, it is becoming clearer that any single "omics" technology might not be able to characterize and unravel complex biological systems, even though high-throughput transcriptomics approaches to analyze RNA at different cellular levels are widely becoming available [113]. Network analysis from various levels of "omics" data (transcriptomics, proteomic and metabolomics) is essential for understanding the entire behavior of cells during complex biological interactions [114]. Currently, this multi-omics approach has been used widely to study stress response in various organisms such as fungi, plants and bacteria [115-117]. However, to the best of our knowledge, there is no study that has been done that utilized multi-omic approaches to unravel dinoflagellates' complexity. We also strongly believe that multi-omics approaches, e.g., integrating transcriptomics with proteomic or metabolomics, can reveal the complexity of dinoflagellates, especially regarding stress responses, as not all stress response molecules in dinoflagellates are regulated at the transcription level.

As stated by Feder and Walser [118], transcriptomic approaches are a means for revealing candidate RNA for novel genes; however, the study should not end with transcriptomics itself. Functional analysis using either targeted gene knockout or over-expression is an effective means for further investigation and extremely useful to confirm and strengthen the findings from transcriptomics data analysis. To date, there are very few studies that have demonstrated successful transformation of genes in dinoflagellates [119-121]. A powerful tool for gene-phenotype interaction is targeted gene knockout/knockdown using RNAi or CRISPR-Cas9 $[122,123]$. The miRNA profile of S. microadriaticum revealed the presence of a complete RNA interference (RNAi) machinery most likely serving as an alternative of regulating gene expression [31]. This finding opens up new possibilities for utilizing targeted gene silencing based on RNAi to generate dinoflagellate knockdown mutants. Recently, CRISPR-Cas9 methods have been successfully generated stable targeted gene knockout 
mutation in the marine diatom Phaeodactylum tricornutum. However, utilizing the same method in marine dinoflagellates is a bit challenging due to the large copy number of target DNA and permanently-condensed chromatin [123,124].

The development of dinoflagellate model organisms will likely benefit the dinoflagellate transcriptomics field, providing invaluable resources for future study. Model organisms have major advantages over a non-model organism due to the availability of vast genomic resources to aid transcriptomics data analysis including gene annotations and prediction of gene interactions [125]. Annotation of non-model organisms like dinoflagellates based on the annotations from their closest model relatives and several limitations have been identified in this approach $[125,126]$. Dinoflagellates from genus Symbiodinium might be suitable candidates for dinoflagellate models as they have the smallest genome size and are the only dinoflagellates with an available draft genome [14-16]. Furthermore, the biological processes of this genus are widely studied both at the cellular and molecular level $[127,128]$. However, extensive studies need to be done before we can develop a model organism for dinoflagellates, as we are still far from meeting model organism criteria in terms of the knowledge and the understanding regarding the biological processes and the life cycle compared to other established model organisms [129].

This review summarizes the recent status in the transcriptomics studies of marine dinoflagellates. All experiments demonstrated that transcriptomics are powerful tools to identify genes in dinoflagellates especially related to growth regulation, toxin biosynthesis, HABs dynamics, dinoflagellates' phylogeny and symbiosis. In future, the combination of transcriptomic approaches with other "omics" approaches will likely deepen our knowledge and understanding regarding dinoflagellates complexity. Beyond this, functional analysis such as gene transformation and gene knockout will bring us closer to elucidating gene function in dinoflagellates.

Acknowledgments: This research was supported by Universiti Kebangsaan Malaysia under the research grant GGPI-2016-002.

Author Contributions: M.A.A. drafted the manuscript. A.A., G.U. and H.B. edited and added valuable insights into the manuscript. All authors read and approved the final manuscript.

Conflicts of Interest: The authors declare no conflict of interest.

\section{References}

1. Lu, Y.; Wohlrab, S.; Groth, M.; Glöckner, G.; Guillou, L.; John, U. Transcriptomic profiling of Alexandrium fundyense during physical interaction with or exposure to chemical signals from the parasite Amoebophrya. Mol. Ecol. 2016, 25, 1294-1307. [CrossRef] [PubMed]

2. Totti, C.; Accoroni, S.; Cerino, F.; Cucchiari, E.; Romagnoli, T. Ostreopsis ovata bloom along the Conero Riviera (northern Adriatic Sea): Relationships with environmental conditions and substrata. Harmful Algae 2010, 9 , 233-239. [CrossRef]

3. Taş, S.; Okuş, E. A review on the bloom dynamics of a harmful dinoflagellate Prorocentrum minimum in the Golden Horn Estuary. Turk. J. Fish. Aquat. Sci. 2011, 11, 523-531. [CrossRef]

4. Corinaldesi, C.; Barucca, M.; Luna, G.M.; Dell'Anno, A. Preservation, origin and genetic imprint of extracellular DNA in permanently anoxic deep-sea sediments. Mol. Ecol. 2011, 20, 642-654. [CrossRef] [PubMed]

5. Canini, N.D.; Metillo, E.B.; Azanza, R.V. Monsoon-influenced phytoplankton community structure in a Philippine mangrove estuary. Trop. Ecol. 2013, 54, 331-343.

6. Rosic, N.; Ling, E.Y.S.; Chan, C.-K.K.; Lee, H.C.; Kaniewska, P.; Edwards, D.; Dove, S.; Hoegh-Guldberg, O. Unfolding the secrets of coral-Algal symbiosis. ISME J. 2015, 9, 844-856. [CrossRef] [PubMed]

7. Gímez, M.I.; Piola, A.R.; Kattner, G.; Alder, V.A. Biomass of autotrophic dinoflagellates under weak vertical stratification and contrasting chlorophyll levels in subantarctic shelf waters. J. Plankton Res. 2011, 33, 1304-1310. [CrossRef] 
8. Jeong, H.J.; Du Yoo, Y.; Kang, N.S.; Lim, A.S.; Seong, K.A.; Lee, S.Y.; Nam, S.W. Heterotrophic feeding as a newly identified survival strategy of the dinoflagellate Symbiodinium. Proc. Natl. Acad. Sci. USA 2012, 109, 12604-12609. [CrossRef] [PubMed]

9. Xiang, T.; Nelson, W.; Rodriguez, J.; Tolleter, D.; Grossman, A.R. Symbiodinium transcriptome and global responses of cells to immediate changes in light intensity when grown under autotrophic or mixotrophic conditions. Plant J. 2015, 82, 67-80. [CrossRef] [PubMed]

10. Meyer, J.M.; Rödelsperger, C.; Eichholz, K.; Tillmann, U.; Cembella, A.; McGaughran, A.; John, U. Transcriptomic characterisation and genomic glimps into the toxigenic dinoflagellate Azadinium spinosum, with emphasis on polykeitde synthase genes. BMC Genom. 2015, 16, 27. [CrossRef] [PubMed]

11. Guo, R.; Wang, H.; Suh, Y.S.; Ki, J.-S. Transcriptomic profiles reveal the genome-wide responses of the harmful dinoflagellate Cochlodinium polykrikoides when exposed to the algicide copper sulfate. BMC Genom. 2016, 17, 29. [CrossRef] [PubMed]

12. Lin, S. Genomic understanding of dinoflagellates. Res. Microbiol. 2011, 16, 551-569. [CrossRef] [PubMed]

13. Wisecaver, J.H.; Hackett, J.D. Dinoflagellate genome evolution. Annu. Rev. Microbiol. 2011, 65, 369-387. [CrossRef] [PubMed]

14. Shoguchi, E.; Shinzato, C.; Kawashima, T.; Gyoja, F.; Mungpakdee, S.; Koyanagi, R.; Hamada, M. Draft assembly of the Symbiodinium minutum nuclear genome reveals dinoflagellate gene structure. Curr. Biol. 2013, 23, 1399-1408. [CrossRef] [PubMed]

15. Lin, S.; Cheng, S.; Song, B.; Zhong, X.; Lin, X.; Li, W.; Cai, M. The Symbiodinium kawagutii genome illuminates dinoflagellate gene expression and coral symbiosis. Science 2015, 350, 691-694. [CrossRef] [PubMed]

16. Aranda, M.; Li, Y.; Liew, Y.J.; Baumgarten, S.; Simakov, O.; Wilson, M.C.; Ryu, T. Genomes of coral dinoflagellate symbionts highlight evolutionary adaptations conducive to a symbiotic lifestyle. Sci. Rep. 2016, 6, 39734. [CrossRef] [PubMed]

17. Ekblom, R.; Galindo, J. Applications of next generation sequencing in molecular ecology of non-model organisms. Heredity 2011, 107, 1-15. [CrossRef] [PubMed]

18. Zhao, S.; Fung-Leung, W.P.; Bittner, A.; Ngo, K.; Liu, X. Comparison of RNA-Seq and microarray in transcriptome profiling of activated T cells. PLoS ONE 2014, 9, e78644. [CrossRef] [PubMed]

19. Price, D.C.; Farinholt, N.; Gates, C.; Shumaker, A.; Wagner, N.E.; Bienfang, P.; Bhattacharya, D. Analysis of Gambierdiscus transcriptome data supports ancient origins of mixotrophic pathways in dinoflagellates. Environ. Microbiol. 2016, 18, 4501-4510. [CrossRef] [PubMed]

20. Zhuang, Y.; Zhang, H.; Hannick, L.; Lin, S. Metatranscriptome profiling reveals versatile N-nutrient utilization, $\mathrm{CO}_{2}$ limitation, oxidative stress, and active toxin production in an Alexandrium fundyense bloom. Harmful Algae 2015, 42, 60-70. [CrossRef]

21. Lidie, K.B.; Van Dolah, F.M. Spliced leader RNA-mediated trans-splicing in a dinoflagellate, Karenia brevis. J. Eukaryot. Microbiol. 2007, 54, 427-435. [CrossRef] [PubMed]

22. Zhang, H.; Hou, Y.; Miranda, L.; Campbell, D.A.; Sturm, N.R.; Gaasterland, T.; Lin, S. Spliced leader RNA trans-splicing in dinoflagellates. Proc. Natl. Acad. Sci. USA 2007, 104, 4618-4623. [CrossRef] [PubMed]

23. Zhang, H.; Zhuang, Y.; Gill, J.; Lin, S. Proof that dinoflagellate spliced leader (DinoSL) is a useful hook for fishing dinoflagellate transcripts from mixed microbial samples: Symbiodinium kawagutii as a case study. Protist 2013, 164, 510-527. [CrossRef] [PubMed]

24. Hu, Z.; Duan, S.; Xu, N.; Mulholland, M.R. Growth and nitrogen uptake kinetics in cultured Prorocentrum donghaiense. PLoS ONE 2014, 9, e94030. [CrossRef] [PubMed]

25. Rizzo, P.J. Those amazing dinoflagellate chromosomes. Cell Res. 2013, 13, 215-217. [CrossRef] [PubMed]

26. Lin, S.; Zhang, H.; Zhuang, Y.; Tran, B.; Gill, J. Spliced leader-based metatranscriptomic analyses lead to recognition of hidden genomic features in dinoflagellates. Proc. Natl. Acad. Sci. USA 2010, 107, 20033-20038. [CrossRef] [PubMed]

27. Roy, S.; Morse, D. A full suite of histone and histone modifying genes are transcribed in the dinoflagellate lingulodinium. PLoS ONE 2012, 7, e34340. [CrossRef] [PubMed]

28. Bayer, T.; Aranda, M.; Sunagawa, S.; Yum, L.K.; DeSalvo, M.K.; Lindquist, E.; Coffroth, M.A.; Voolstra, C.R.; Medina, M. Symbiodinium transcriptomes: Genome insights into the dinoflagellate symbionts of reef-building corals. PLoS ONE 2012, 7, e35269. [CrossRef] [PubMed] 
29. Kohli, G.S.; John, U.; Figueroa, R.I.; Rhodes, L.L.; Harwood, D.T.; Groth, M.; Bolch, C.J.S.; Murray, S.A. Polyketide synthesis genes associated with toxin production in two species of Gambierdiscus (Dinophyceae). BMC Genom. 2015, 16, 410. [CrossRef] [PubMed]

30. Toulza, E.; Shin, M.S.; Blanc, G.; Audic, S.; Laabir, M.; Collos, Y.; Grzebyk, D. Gene expression in proliferating cells of the dinoflagellate Alexandrium catenella (Dinophyceae). Appl. Environ. Microbiol. 2010, 76, 4521-4529. [CrossRef] [PubMed]

31. Baumgarten, S.; Bayer, T.; Aranda, M.; Liew, Y.J.; Carr, A.; Micklem, G.; Voolstra, C.R. Integrating microRNA and mRNA expression profiling in Symbiodinium microadriaticum, a dinoflagellate symbiont of reef-building corals. BMC Genom. 2013, 14, 704. [CrossRef] [PubMed]

32. Gao, D.; Qiu, L.; Hou, Z.; Zhang, Q.; Wu, J.; Gao, Q.; Song, L. Computational identification of microRNAs from the expressed sequence tags of toxic dinoflagellate Alexandrium tamarense. Evol. Bioinform. 2013, 9, 479-485. [CrossRef] [PubMed]

33. Geng, H.; Sui, Z.; Zhang, S.; Du, Q.; Ren, Y.; Liu, Y.; Ma, Q. Identification of microRNAs in the toxigenic Dinoflagellate Alexandrium catenella by high-throughput illumina sequencing and bioinformatic analysis. PLoS ONE 2015, 10, e0138709. [CrossRef] [PubMed]

34. Shi, X.; Lin, X.; Li, L.; Li, M.; Palenik, B.; Lin, S. Transcriptomic and microRNAomic profiling reveals multi-faceted mechanisms to cope with phosphate stress in a dinoflagellate. ISME J. 2017, 11, 2209-2218. [CrossRef] [PubMed]

35. Dagenais-Bellefeuille, S.; Beauchemin, M.; Morse, D. miRNAs do not regulate circadian protein synthesis in the dinoflagellate Lingulodinium polyedrum. PLoS ONE 2017, 12, e0168817. [CrossRef] [PubMed]

36. Levin, R.A.; Beltran, V.H.; Hill, R.; Kjelleberg, S.; McDougald, D.; Steinberg, P.D.; Van Oppen, M.J.H. Sex, Scavengers, and Chaperones: Transcriptome Secrets of Divergent Symbiodinium Thermal Tolerances. Mol. Biol. Evol. 2016, 33, 2201-2215. [CrossRef] [PubMed]

37. Gierz, S.L.; Forêt, S.; Leggat, W. Transcriptomic analysis of thermally stressed Symbiodinium reveals differential expression of stress and metabolism genes. Front. Plant Sci. 2017, 8, 271. [CrossRef] [PubMed]

38. Morey, J.S.; Monroe, E.A.; Kinney, A.L.; Beal, M.; Johnson, J.G.; Hitchcock, G.L.; Van Dolah, F.M. Transcriptomic response of the red tide dinoflagellate, Karenia brevis, to nitrogen and phosphorus depletion and addition. BMC Genom. 2011, 12, 346. [CrossRef] [PubMed]

39. Moustafa, A.; Evans, A.N.; Kulis, D.M.; Hackett, J.D.; Erdner, D.L.; Anderson, D.M.; Bhattacharya, D. Transcriptome profiling of a toxic dinoflagellate reveals a gene-rich protist and a potential impact on gene expression due to bacterial presence. PLoS ONE 2010, 5, e9688. [CrossRef] [PubMed]

40. Cooper, J.T.; Sinclair, G.A.; Wawrik, B. Transcriptome analysis of Scrippsiella trochoidea CCMP 3099 reveals physiological changes related to nitrate depletion. Front. Microbiol. 2016, 7, 639. [CrossRef] [PubMed]

41. Erdner, D.L.; Anderson, D.M. Global transcriptional profiling of the toxic dinoflagellate Alexandrium fundyense using massively parallel signature sequencing. BMC Genom. 2016, 7, 88. [CrossRef]

42. Yang, I.; Beszteri, S.; Tillmann, U.; Cembella, A.; John, U. Growth-and nutrient-dependent gene expression in the toxigenic marine dinoflagellate Alexandrium minutum. Harmful Algae 2011, 12, 55-69. [CrossRef]

43. Luo, H.; Lin, X.; Li, L.; Lin, L.; Zhang, C.; Lin, S. Transcriptomic and physiological analyses of the dinoflagellate Karenia mikimotoi reveal non-alkaline phosphatase-based molecular machinery of ATP utilisation. Environ. Microbiol. 2017, 19, 4506-4518. [CrossRef] [PubMed]

44. Zhang, C.; Luo, H.; Huang, L.; Lin, S. Molecular mechanism of glucose-6-phosphate utilization in the dinoflagellate Karenia mikimotoi. Harmful Algae 2017, 67. [CrossRef] [PubMed]

45. Leggat, W.; Hoegh-Guldberg, O.; Dove, S.; Yellowlees, D. Analysis of an EST library from the dinoflagellate (Symbiodinium sp.) symbiont of reef-building corals. J. Phycol. 2007, 43, 1010-1021. [CrossRef]

46. Ladner, J.T.; Barshis, D.J.; Palumbi, S.R. Protein evolution in two co-occurring types of Symbiodinium: An exploration into the genetic basis of thermal tolerance in Symbiodinium clade D. BMC Evol. Biol. 2012, 12, 217. [CrossRef] [PubMed]

47. Barshis, D.J.; Ladner, J.T.; Oliver, T.A.; Palumbi, S.R. Lineage-specific transcriptional profiles of Symbiodinium spp. Unaltered by heat stress in a coral host. Mol. Biol. Evol. 2014, 31, 1343-1352. [CrossRef] [PubMed]

48. Yang, I.; Selander, E.; Pavia, H.; John, U. Grazer-induced toxin formation in dinoflagellates: A transcriptomic model study. Eur. J. Phycol. 2011, 46, 66-73. [CrossRef]

49. Ryan, D.E.; Campbell, L. Identification and phylogeny of putative PEPC genes in three toxin-producing Karenia (Dinophyta) species. J. Phycol. 2016, 52, 618-625. [CrossRef] [PubMed] 
50. Lowe, C.D.; Mello, L.V.; Samatar, N.; Martin, L.E.; Montagnes, D.J.S.; Watts, P.C. The transcriptome of the novel dinoflagellate Oxyrrhis marina (Alveolata: Dinophyceae): Response to salinity examined by 454 sequencing. BMC Genom. 2011, 12, 519. [CrossRef] [PubMed]

51. Liu, Z.; Koid, A.E.; Terrado, R.; Campbell, V.; Caron, D.A.; Heidelberg, K.B. Changes in gene expression of Prymnesium parvum induced by nitrogen and phosphorus limitation. Front. Microbiol. 2015, 6, 631. [CrossRef] [PubMed]

52. Li, M.; Li, L.; Shi, X.; Lin, L.; Lin, S. Effects of phosphorus deficiency and adenosine $5^{\prime}$-triphosphate (ATP) on growth and cell cycle of the dinoflagellate Prorocentrum donghaiense. Harmful Algae 2015, 47, 35-41. [CrossRef]

53. Li, M.; Shi, X.; Guo, C.; Lin, S. Phosphorus deficiency inhibits cell division but not growth in the dinoflagellate Amphidinium carterae. Front. Microbiol. 2016, 7, 826. [CrossRef] [PubMed]

54. Jauzein, C.; Labry, C.; Youenou, A.; Quéré, J.; Delmas, D.; Collos, Y. Growth and phosphorus uptake by the toxic dinoflagellate Alexandrium catenella (Dinophyceae) in response to phosphate limitation. J. Phycol. 2010, 46, 926-936. [CrossRef]

55. Ebenezer, V.; Lim, W.A.; Ki, J.S. Effects of the algicides $\mathrm{CuSO}_{4}$ and $\mathrm{NaOCl}$ on various physiological parameters in the harmful dinoflagellate Cochlodinium polykrikoides. J. Appl. Phycol. 2014, 26, 2357-2365. [CrossRef]

56. Van Dolah, F.M.; Lidie, K.B.; Morey, J.S.; Brunelle, S.A.; Ryan, J.C.; Monroe, E.A.; Haynes, B.L. Microarray Analysis of Diurnal-And Circadian-Regulated Genes in the Florida Red-Tide Dinoflagellate Karenia Brevis (Dinophyceae). J. Phycol. 2007, 43, 741-752. [CrossRef]

57. Brunelle, S.A.; Van Dolah, F.M. Post-transcriptional Regulation of S-Phase Genes in the Dinoflagellate, Karenia brevis. J. Eukaryot. Microbiol. 2011, 58, 373-382. [CrossRef] [PubMed]

58. Selander, E.; Thor, P.; Toth, G.; Pavia, H. Copepods induce paralytic shellfish toxin production in marine dinoflagellates. Proc. R. Soc. B Biol. Sci. 2006, 273, 1673-1680. [CrossRef] [PubMed]

59. Bergkvist, J.; Selander, E.; Pavia, H. Induction of toxin production in dinoflagellates: The grazer makes a difference. Oecologia 2008, 156, 147-154. [CrossRef] [PubMed]

60. Wohlrab, S.; Iversen, M.H.; John, U. A molecular and co-evolutionary context for grazer induced toxin production in Alexandrium tamarense. PLoS ONE 2010, 5, e15039. [CrossRef] [PubMed]

61. Zhang, S.; Sui, Z.; Chang, L.; Kang, K.; Ma, J.; Kong, F.; Zhou, W.; Wang, J.; Guo, L.; Geng, H.; et al. Transcriptome de novo assembly sequencing and analysis of the toxic dinoflagellate Alexandrium catenella using the Illumina platform. Gene 2014, 537, 285-293. [CrossRef] [PubMed]

62. Taroncher-Oldenburg, G.; Anderson, D.M. Identification and characterization of three differentially expressed genes, encoding S-adenosylhomocysteine hydrolase, methionine aminopeptidase, and a histone-like protein, in the toxic dinoflagellate Alexandrium fundyense. Appl. Environ. Microbiol. 2000, 66, 2105-2112. [CrossRef] [PubMed]

63. Snyder, R.V.; Gibbs, P.D.L.; Palacios, A.; Abiy, L.; Dickey, R.; Lopez, J.V.; Rein, K.S. Polyketide synthase genes from marine dinoflagellates. Mar. Biotechnol. 2003, 5, 1-12. [CrossRef] [PubMed]

64. Hosoi-Tanabe, S.; Tomishima, S.; Nagai, S.; Sako, Y. Identification of a gene induced in conjugation-promoted cells of toxic marine dinoflagellates Alexandrium tamarense and Alexandrium catenella using differential display analysis. FEMS Microbiol. Lett. 2015, 251, 161-168. [CrossRef] [PubMed]

65. Kellmann, R.; Michali, T.K.; Neilan, B.A. Identification of a saxitoxin biosynthesis gene with a history of frequent horizontal gene transfers. J. Mol. Evol. 2008, 67, 526-538. [CrossRef] [PubMed]

66. Kellmann, R.; Stüken, A.; Orr, R.J.; Svendsen, H.M.; Jakobsen, K.S. Biosynthesis and molecular genetics of polyketides in marine dinoflagellates. Mar. Drugs 2010, 8, 1011-1048. [CrossRef]

67. Zhang, Y.; Zhang, S.F.; Lin, L.; Wang, D.Z. Comparative transcriptome analysis of a toxin-producing dinoflagellate Alexandrium catenella and its non-toxic mutant. Mar. Drugs 2014, 12, 5698-5718. [CrossRef] [PubMed]

68. Yang, I.; John, U.; Beszteri, S.; Glöckner, G.; Krock, B.; Goesmann, A.; Cembella, A.D. Comparative gene expression in toxic versus non-toxic strains of the marine dinoflagellate Alexandrium minutum. BMC Genom. 2010, 11, 248. [CrossRef] [PubMed]

69. Stüken, A.; Orr, R.J.S.; Kellmann, R.; Murray, S.A.; Neilan, B.A.; Jakobsen, K.S. Discovery of nuclear-encoded genes for the neurotoxin saxitoxin in dinoflagellates. PLoS ONE 2011, 6, e20096. [CrossRef] [PubMed] 
70. Salcedo, T.; Upadhyay, R.J.; Nagasaki, K.; Bhattacharya, D. Dozens of toxin-related genes are expressed in a nontoxic strain of the dinoflagellate Heterocapsa circularisquama. Mol. Biol. Evol. 2012, 29, 1503-1506. [CrossRef] [PubMed]

71. Pawlowiez, R.; Morey, J.S.; Darius, H.T.; Chinain, M.; Van Dolah, F.M. Transcriptome sequencing reveals single domain Type I-like polyketide synthases in the toxic dinoflagellate Gambierdiscus polynesiensis. Harmful Algae 2014, 36, 29-37. [CrossRef]

72. Monroe, E.A.; Van Dolah, F.M. The toxic dinoflagellate Karenia brevis encodes novel type I-like polyketide synthases containing discrete catalytic domains. Protist 2008, 159, 471-482. [CrossRef] [PubMed]

73. Monroe, E.A.; Johnson, J.G.; Wang, Z.; Pierce, R.K.; Van Dolah, F.M. Characterization and Expression of Nuclear-Encoded Polyketide Synthases in the Brevetoxin-Producing Dinoflagellate Karenia Brevis. J. Phycol. 2010, 46, 541-552. [CrossRef]

74. Harlow, L.D.; Negri, A.; Hallegraeff, G.M.; Koutoulis, A. Sam, Sahh and Map gene expression during cell division and paralytic shellfish toxin production of Alexandrium catenella (Dinophyceae). Phycologia 2007, 46, 666-674. [CrossRef]

75. Hackett, J.D.; Wisecaver, J.H.; Brosnahan, M.L.; Kulis, D.M.; Anderson, D.M.; Bhattacharya, D.; Gerald Plumley, F.; Erdner, D.L. Evolution of saxitoxin synthesis in cyanobacteria and dinoflagellates. Mol. Biol. Evol. 2013, 30, 70-78. [CrossRef] [PubMed]

76. Ryan, D.E.; Pepper, A.E.; Campbell, L. De novo assembly and characterization of the transcriptome of the toxic dinoflagellate Karenia brevis. BMC Genom. 2014, 15, 888. [CrossRef] [PubMed]

77. Stewart, F.J.; Ulloa, O.; DeLong, E.F. Microbial metatranscriptomics in a permanent marine oxygen minimum zone. Environ. Microbiol. 2012, 14, 23-40. [CrossRef] [PubMed]

78. Shi, Y.; Tyson, G.W.; DeLong, E.F. Metatranscriptomics reveals unique microbial small RNAs in the ocean's water column. Nature 2009, 459, 266-269. [CrossRef] [PubMed]

79. Cooper, E.D.; Bentlage, B.; Gibbons, T.R.; Bachvaroff, T.R.; Delwiche, C.F. Metatranscriptome profiling of a harmful algal bloom. Harmful Algae 2014, 37, 75-83. [CrossRef] [PubMed]

80. Gong, W.; Browne, J.; Hall, N.; Schruth, D.; Paerl, H.; Marchetti, A. Molecular insights into a dinoflagellate bloom. ISME J. 2016, 11, 439-452. [CrossRef] [PubMed]

81. Amo, M.; Suzuki, N.; Kawamura, H.; Yamaguchi, A.; Takano, Y.; Horiguchi, T. Sterol composition of dinoflagellates: Different abundance and composition in heterotrophic species and resting cysts. Geochem. J. 2010, 44, 225-231. [CrossRef]

82. Kang, Y.; Tang, Y.Z.; Taylor, G.T.; Gobler, C.J. Discovery of a resting stage in the harmful, brown-tide-causing pelagophyte, Aureoumbra lagunensis: A mechanism potentially facilitating recurrent blooms and geographic expansion. J. Phycol. 2017, 53, 118-130. [CrossRef] [PubMed]

83. Andersson, J.O. Lateral gene transfer in eukaryotes. Cell. Mol. Life Sci. 2005, 62, 1182-1197. [CrossRef] [PubMed]

84. Minge, M.A.; Shalchian-Tabrizi, K.; Tørresen, O.K.; Takishita, K.; Probert, I.; Inagaki, Y.; Jakobsen, K.S. A phylogenetic mosaic plastid proteome and unusual plastid-targeting signals in the green-colored dinoflagellate Lepidodinium chlorophorum. BMC Evol. Biol. 2010, 10, 191. [CrossRef] [PubMed]

85. Mungpakdee, S.; Shinzato, C.; Takeuchi, T.; Kawashima, T.; Koyanagi, R.; Hisata, K.; Satoh, N. Massive gene transfer and extensive RNA editing of a symbiotic dinoflagellate plastid genome. Genome Biol. Evol. 2014, 6, 1408-1422. [CrossRef] [PubMed]

86. Burki, F.; Imanian, B.; Hehenberger, E.; Hirakawa, Y.; Maruyama, S.; Keeling, P.J. Endosymbiotic gene transfer in tertiary plastid-containing dinoflagellates. Eukaryot. Cell 2014, 13, 246-255. [CrossRef] [PubMed]

87. Dorrell, R.G.; Hinksman, G.A.; Howe, C.J. Diversity of transcripts and transcript processing forms in plastids of the dinoflagellate alga Karenia mikimotoi. Plant Mol. Biol. 2016, 90, 233-247. [CrossRef] [PubMed]

88. Caron, D.A.; Alexander, H.; Allen, A.E.; Archibald, J.M.; Armbrust, E.V.; Bachy, C.; Heidelberg, K.B. Probing the evolution, ecology and physiology of marine protists using transcriptomics. Nat. Rev. Microbiol. 2017, 15, 6-20. [CrossRef] [PubMed]

89. Wisecaver, J.H.; Hackett, J.D. Transcriptome analysis reveals nuclear-encoded proteins for the maintenance of temporary plastids in the dinoflagellate Dinophysis acuminate. BMC Genom. 2010, 11, 366. [CrossRef] [PubMed]

90. Wang, D.Z.; Zhang, H.; Zhang, Y.; Zhang, S.F. Marine dinoflagellate proteomics: Current status and future perspectives. J. Proteom. 2014, 105, 121-132. [CrossRef] [PubMed] 
91. McGinty, E.S.; Pieczonka, J.; Mydlarz, L.D. Variations in reactive oxygen release and antioxidant activity in multiple Symbiodinium types in response to elevated temperature. Microb. Ecol. 2012, 64, 1000-1007. [CrossRef] [PubMed]

92. Krueger, T.; Becker, S.; Pontasch, S.; Dove, S.; Hoegh-Guldberg, O.; Leggat, W.; Davy, S.K. Antioxidant plasticity and thermal sensitivity in four types of Symbiodinium sp. J. Phycol. 2014, 50, 1035-1047. [CrossRef] [PubMed]

93. Louis, Y.D.; Kaullysing, D.; Gopeechund, A.; Mattan-Moorgawa, S.; Bahorun, T.; Dyall, S.D.; Bhagooli, R. In hospite Symbiodinium photophysiology and antioxidant responses in Acropora muricata on a coast-reef scale: Implications for variable bleaching patterns. Symbiosis 2016, 68, 61-72. [CrossRef]

94. Higuchi, T.; Fujimura, H.; Arakaki, T.; Oomori, T. Activities of antioxidant enzymes (SOD and CAT) in the coral Galaxea fascicularis against increased hydrogen peroxide concentrations in seawater. In Proceedings of the 11th International Coral Reef Symposium, Ft. Lauderdale, FL, USA, 7-11 July 2008.

95. Abedi, T.; Pakniyat, H. Antioxidant enzyme changes in response to drought stress in ten cultivars of oilseed rape (Brassica napus L.). Czech J. Genet. Plant Breed. 2010, 46, 27-34.

96. Hu, L.; Li, H.; Pang, H.; Fu, J. Responses of antioxidant gene, protein and enzymes to salinity stress in two genotypes of perennial ryegrass (Lolium perenne) differing in salt tolerance. J. Plant Physiol. 2012, 169, 146-156. [CrossRef] [PubMed]

97. Wood-Charlson, E.M.; Hollingsworth, L.L.; Krupp, D.A.; Weis, V.M. Lectin/glycan interactions play a role in recognition in a coral/dinoflagellate symbiosis. Cell. Microbiol. 2006, 8, 1985-1993. [CrossRef] [PubMed]

98. Logan, D.D.; LaFlamme, A.C.; Weis, V.M.; Davy, S.K. Flow-cytometric characterization of the cell-surface glycans of symbiotic dinoflagellates (symbiodinium spp.). J. Phycol. 2010, 46, 525-533. [CrossRef]

99. Song, B.; Morse, D.; Song, Y.; Fu, Y.; Lin, X.; Wang, W.; Lin, S. Comparative genomics reveals two major bouts of gene retroposition coinciding with crucial periods of Symbiodinium evolution. Genome Biol. Evol. 2017, 9, 2037-2047. [CrossRef] [PubMed]

100. Kosuta, S.; Hazledine, S.; Sun, J.; Miwa, H.; Morris, R.J.; Downie, J.A.; Oldroyd, G.E. Differential and chaotic calcium signatures in the symbiosis signaling pathway of legumes. Proc. Natl. Acad. Sci. USA 2008, 105, 9823-9828. [CrossRef] [PubMed]

101. Singh, S.; Parniske, M. Activation of calcium-and calmodulin-dependent protein kinase (CCaMK), the central regulator of plant root endosymbiosis. Curr. Opin. Plant Biol. 2012, 15, 444-453. [CrossRef] [PubMed]

102. Lidie, K.B.; Ryan, J.C.; Barbier, M.; Van Dolah, F.M. Gene expression in Florida red tide dinoflagellate Karenia brevis: Analysis of an expressed sequence tag library and development of DNA microarray. Mar. Biotechnol. 2005, 7, 481-493. [CrossRef] [PubMed]

103. Zhang, X.; Tian, X.; Ma, L.; Feng, B.; Liu, Q.; Yuan, L.; Yang, Q. Biodiversity of the symbiotic bacteria associated with toxic marine Dinoflagellate Alexandrium tamarense. J. Biosci. Med. 2015, 3, 23. [CrossRef]

104. Hold, G.L.; Smith, E.A.; Harry Birkbeck, T.; Gallacher, S. Comparison of paralytic shellfish toxin (PST) production by the dinoflagellates Alexandrium lusitanicum NEPCC 253 and Alexandrium tamarense NEPCC 407 in the presence and absence of bacteria. FEMS Microbiol. Ecol. 2001, 36, 223-234. [CrossRef] [PubMed]

105. Croft, M.T.; Lawrence, A.D.; Raux-Deery, E.; Warren, M.J.; Smith, A.G. Algae acquire vitamin B12 through a symbiotic relationship with bacteria. Nature 2005, 438, 90-93. [CrossRef] [PubMed]

106. Wang, X.; Li, Z.; Su, J.; Tian, Y.; Ning, X.; Hong, H.; Zheng, T. Lysis of a red-tide causing alga, Alexandrium tamarense, caused by bacteria from its phycosphere. Biol. Control 2010, 52, 123-130. [CrossRef]

107. Wang, H.; Tomasch, J.; Jarek, M.; Wagner-Döbler, I. A dual-species co-cultivation system to study the interactions between Roseobacters and dinoflagellates. Front. Microbiol. 2014, 5, 311. [CrossRef] [PubMed]

108. Seyedsayamdost, M.R.; Case, R.J.; Kolter, R.; Clardy, J. The Jekyll-and-Hyde chemistry of Phaeobacter gallaeciensis. Nat. Chem. 2011, 3, 331-335. [CrossRef] [PubMed]

109. Whitehead, A. Comparative genomics in ecological physiology: Toward a more nuanced understanding of acclimation and adaptation. J. Exp. Biol. 2012, 215, 884-891. [CrossRef] [PubMed]

110. Weber, M.; Trampczynska, A.; Clemens, S. Comparative transcriptome analysis of toxic metal responses in Arabidopsis thaliana and the Cd2+-hypertolerant facultative metallophyte Arabidopsis halleri. Plant Cell Environ. 2006, 29, 950-963. [CrossRef] [PubMed]

111. Brinker, M.; Brosché, M.; Vinocur, B.; Abo-Ogiala, A.; Fayyaz, P.; Janz, D.; Altman, A. Linking the salt transcriptome with physiological responses of a salt-resistant Populus species as a strategy to identify genes important for stress acclimation. Plant Physiol. 2010, 154, 1697-1709. [CrossRef] [PubMed] 
112. Mustroph, A.; Lee, S.C.; Oosumi, T.; Zanetti, M.E.; Yang, H.; Ma, K.; Bailey-Serres, J. Cross-kingdom comparison of transcriptomic adjustments to low-oxygen stress highlights conserved and plant-specific responses. Plant Physiol. 2010, 152, 1484-1500. [CrossRef] [PubMed]

113. Zhang, W.; Li, F.; Nie, L. Integrating multiple 'omics' analysis for microbial biology: Application and methodologies. Microbiology 2010, 156, 287-301. [CrossRef] [PubMed]

114. Zhuang, J.; Zhang, J.; Hou, X.L.; Wang, F.; Xiong, A.S. Transcriptomic, proteomic, metabolomic and functional genomic approaches for the study of abiotic stress in vegetable crops. Crit. Rev. Plant Sci. 2014, 33, 225-237. [CrossRef]

115. Kohlstedt, M.; Sappa, P.K.; Meyer, H.; Maaß, S.; Zaprasis, A.; Hoffmann, T.; Lalk, M. Adaptation of Bacillus subtilis carbon core metabolism to simultaneous nutrient limitation and osmotic challenge: A multi-omics perspective. Environ. Microbiol. 2014, 16, 1898-1917. [CrossRef] [PubMed]

116. Pomraning, K.R.; Kim, Y.M.; Nicora, C.D.; Chu, R.K.; Bredeweg, E.L.; Purvine, S.O.; Baker, S.E. Multi-omics analysis reveals regulators of the response to nitrogen limitation in Yarrowia lipolytica. BMC Genom. 2016, 17, 138. [CrossRef] [PubMed]

117. Savoi, S.; Wong, D.C.; Degu, A.; Herrera, J.C.; Bucchetti, B.; Peterlunger, E.; Castellarin, S.D. Multi-omics and integrated network analyses reveal new insights into the systems relationships between metabolites, structural genes, and transcriptional regulators in developing grape berries (Vitis vinifera L.) exposed to water deficit. Front. Plant Sci. 2017, 8, 1124. [CrossRef] [PubMed]

118. Feder, M.E.; Walser, J.C. The biological limitations of transcriptomics in elucidating stress and stress responses. J. Evol. Biol. 2005, 18, 901-910. [CrossRef] [PubMed]

119. Te, M.R.; Miller, D.J. Genetic transformation of dinoflagellates (Amphidinium and Symbiodinium): Expression of GUS in microalgae using heterologous promoter constructs. Plant J. 1998, 13, 427-435. [CrossRef]

120. Ho, P.; Kong, K.F.; Chan, Y.H.; Tsang, J.S.; Wong, J.T. An unusual S-adenosylmethionine synthetase gene from dinoflagellate is methylated. BMC Mol. Biol. 2007, 8, 87. [CrossRef] [PubMed]

121. Suzuki-Ogoh, C.; Wu, C.; Ohmiya, Y. C-terminal region of the active domain enhances enzymatic activity in dinoflagellate luciferase. Photochem. Photobiol. Sci. 2008, 7, 208-211. [CrossRef] [PubMed]

122. Sitnicka, D.; Figurska, K.; Orzechowski, S. Functional Analysis of Genes. Adv. Cell Biol. 2010, 2, 1-16. [CrossRef]

123. Nymark, M.; Sharma, A.K.; Sparstad, T.; Bones, A.M.; Winge, P. A CRISPR/Cas9 system adapted for gene editing in marine algae. Sci. Rep. 2016, 6, 24951. [CrossRef] [PubMed]

124. Murray, S.A.; Suggett, D.J.; Doblin, M.A.; Kohli, G.S.; Seymour, J.R.; Fabris, M.; Ralph, P.J. Unravelling the functional genetics of dinoflagellates: A review of approaches and opportunities. Perspect. Phycol. 2016, 3, 37-52. [CrossRef]

125. Alvarez, M.; Schrey, A.W.; Richards, C.L. Ten years of transcriptomics in wild populations: What have we learned about their ecology and evolution? Mol. Ecol. 2015, 24, 710-725. [CrossRef] [PubMed]

126. Hackett, J.D.; Scheetz, T.E.; Yoon, H.S.; Soares, M.B.; Bonaldo, M.F.; Casavant, T.L.; Bhattacharya, D. Insights into a dinoflagellate genome through expressed sequence tag analysis. BMC Genom. 2005, 6, 80. [CrossRef] [PubMed]

127. Leggat, W.; Yellowlees, D.; Medina, M. Recent progress in Symbiodinium transcriptomics. J. Exp. Mar. Biol. Ecol. 2011, 408, 120-125. [CrossRef]

128. Davy, S.K.; Allemand, D.; Weis, V.M. Cell biology of cnidarian-dinoflagellate symbiosis. Microbiol. Mol. Biol. Rev. 2012, 76, 229-261. [CrossRef] [PubMed]

129. Harris, E.H. Chlamydomonas as a model organism. Annu. Rev. Plant Biol. 2001, 52, 363-406. [CrossRef] [PubMed]

(C) 2018 by the authors. Licensee MDPI, Basel, Switzerland. This article is an open access article distributed under the terms and conditions of the Creative Commons Attribution (CC BY) license (http://creativecommons.org/licenses/by/4.0/). 